\title{
人工酸性雨中における銅の腐食挙動*
}

\author{
馬飼野信一 ${ }^{* *}$, 深 澤 宜 行 $^{* *}$, 内田 弘** \\ ** 神奈川県工業試験所
}

\section{Copper Corrosion in Simulated Acid Rain*}

\author{
Shin'ichi Magaino**, Yoshiyuki Fukazawa** and Hiroshi Uchida** \\ ** Industrial Research Institute of Kanagawa Prefecture
}

\begin{abstract}
Copper corrosion in a simulated acid rain has been investigated by the electrochemical impedance analysis, the galvanostatic cathodic-polarization, FT-IR and ICP-AES. Effects of $\mathrm{pH}$ and the $\mathrm{Cl}^{-}$concentration on the rate and the mechanism of the corrosion were studied adding $\mathrm{H}_{2} \mathrm{SO}_{4}$ (or $\mathrm{NaOH}$ ) and $\mathrm{NaCl}$ to the simulated acid rain respectively. The corrosion rate increased with decreasing $\mathrm{pH}$, and with increasing $\mathrm{Cl}^{-}$concentration. Warburg impedance resulting from a diffusion process for dissolved oxygen was observed at $\mathrm{pH}$ below about 3 . The rate determining step of corrosion was found to be a film formation/dissolution process at $\mathrm{pH} \geqq 3.5$, and to be a diffusion process for dissolved oxygen at $\mathrm{pH} \leqq 2.9$. The film thickness increased with $\mathrm{Cl}^{-}$addition to the simulated acid rain, but the film formed at the $\mathrm{Cl}^{-}$concentration of $1000 \mathrm{mg} \cdot \mathrm{dm}^{-3}$ was thinner than that of $100 \mathrm{mg} \cdot$ $\mathrm{dm}^{-3}$. This decrease in the film thickness at the $\mathrm{Cl}^{-}$concentration of $1000 \mathrm{mg} \cdot \mathrm{dm}^{-3}$ may result from the formation of $\mathrm{CuCl}$ whose solubility is much greater than that of $\mathrm{Cu}_{2} \mathrm{O}$ which is one of the major components of the film at low $\mathrm{Cl}^{-}$concentrations. The corrosion rate is thought to be controlled by $\mathrm{CuCl}_{2}{ }^{-}$diffusion when the $\mathrm{Cl}^{-}$concentration is high.
\end{abstract}

Key words : copper, corrosion, acid rain, impedance, $\mathrm{pH}, \mathrm{Cl}, \mathrm{FT}-\mathrm{IR}$

\section{1. 緒言}

近年, 亜硫酸ガスや窒素酸化物による大気污染は雨水 の酸性度を高め, その結果屋外金属製構造物の腐食が促 進されるという事態が生じている1),2)。なかでも, 中性 環境で優れた耐食性を示すため建物の屋根や銅像などの 文化財に裸のまま使用されている銅または銅合金の腐食 がとくに著しいと言われている。このような腐食を防止 するためには，まずはじめに酸性雨による銅の腐食反応 機構を明らかにする必要があるが，これまでに実施され ている研究のほとんどは緑青の分析程度にとどまってい

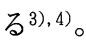

ところで, 銅の溶解過程について Mattsson と Bockris $^{5)}$ は, はじめに $\mathrm{Cu}$ が $\mathrm{Cu}^{+}$になり, ついで $\mathrm{Cu}^{+}$が $\mathrm{Cu}^{2+}$ になるという2 段階反応を提唱し, その後しばら

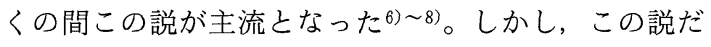

* 第 40, 41 回腐食防食討論会 (那覇, 1993, 松山, 1994) で発表

** =236 横浜市金沢区昭和町 3173(3173, Showamachi, Kanazawa-ku, Yokohama, 236 Japan)
けでは説明がつかない現象もあり, 現在では $\mathrm{Cu}$ が $\mathrm{Cu}^{+}$ になる過程には吸着過程が介在すると言われてい る9) 11)。また, Jardy ら ${ }^{12)}$ は $\mathrm{Cu} / \mathrm{Na}_{2} \mathrm{SO}_{4}+\mathrm{H}_{2} \mathrm{SO}_{4}$ に おける銅の溶解過程を QCM および回転リングディスク を用いて検討し，低電流密度において銅は一価で溶解 し、インピーダンス軌跡には二つの円弧が現れると報告 している。このインピーダンス軌跡が二つの円弧で構成 されるということについては Cordeiro ら ${ }^{13)}$ や Wong ら ${ }^{14)}$ も確認しており, Wong らは高周波数側の円弧は電 荷移動過程に対応し，低周波数側の円弧は電荷移動中間 体の吸着または拡散過程に対応すると推定している。

一方, 銅の溶解過程に対する陰イオンの影響について は, $\mathrm{Cu} / \mathrm{NaCl}(+\mathrm{HCl})$ 系または $\mathrm{Cu} / \mathrm{HCl}$ 系に関する 研究が進んでおり, 溶解反応は $\mathrm{CuCl}_{2}-$ の拡散律速であ ると言われている15) 17)。 $\mathrm{Cl}^{-}$以外の陰イオンも銅の溶 解過程に影響があることは Bockris とEnyo ${ }^{6)}$, Awad

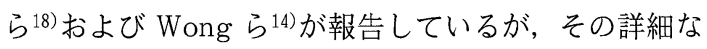
機構については明らかにされていない。

ところで，銅の溶解過程に関するこれまでの研究のほ 
Table 1 Chemical components of simulated acid rain $(\mathrm{pH}=3.5)$.

\begin{tabular}{cc}
\hline \hline Component & $\begin{array}{c}\text { Concentration } \\
/ \mathrm{mg} \mathrm{dm}^{-3}\end{array}$ \\
\hline $\mathrm{F}^{-}$ & 0.098 \\
$\mathrm{Cl}^{-}$ & 1.0 \\
$\mathrm{NO}_{3}{ }^{-}$ & 7.1 \\
$\mathrm{SO}_{4}^{2-}$ & 10.9 \\
$\mathrm{Na}^{+}$ & 0.42 \\
$\mathrm{~K}^{+}$ & 0.11 \\
$\mathrm{Ca}^{2+}$ & 0.049 \\
$\mathrm{Mg}^{2+}$ & 0.051 \\
\hline
\end{tabular}

とんどは酸性雨に比べるとイオン濃度が高く，しかも脱 気した溶液を用いて行われている。したがって，これま でに報告されている結果だけで銅の酸性雨腐食の機構を 論ずることは危険である。そこで本研究では，実際の酸 性雨に近い組成の人工酸性雨を用い, $\mathrm{pH}$ を種々に变え たときの銅の表面状態，腐食速度ならびに反応機構の変 化を定電流カソード分極, 赤外分光分析, ICP 発光分 析および電気化学インピーダンス解析により検討した。 さらに，酸性雨による銅の腐食が海に近いところでとく に著しいという事実に着目し, 人工酸性雨に種々の濃度 の塩素イオンを添加し，その影響について検討した。

\section{2. 実験方法}

\section{1 試験片および試験液}

ハルセル試験用無酸素銅板（(株)山本鍍金試験器製) より各実験に対応した大きさに切り出した試験片を \#600 のエメリー紙で湿式研磨したのち蒸留水で洗浄 し，水分をろ紙で除去してから実験に供した。また，塩 素イオンを添加した試験液中においてインピーダンス軌 跡に及ぼす拡散過程の影響を調べる実験では, 99. 9998 $\%$ の純銅試料 (Aldrich Chemical Co. Inc. 製) を直 径 $8 \mathrm{~mm}$ の円柱状に加工したのちフッ素樹脂中に埋め 込み, 試験面 $0.5 \mathrm{~cm}^{2}$ の回転円盤電極としたものを試 験極とした。

試験液には米国商務省標準局（NIST）の標準試料に 準拠して調製した $\mathrm{pH}=3.5$ の人工酸性雨（Table 1) に $\mathrm{H}_{2} \mathrm{SO}_{4}$ または $\mathrm{NaOH}$ を添加して $\mathrm{pH}$ を 2.1〜4.3の 範囲で変化させたもの，および $10 〜 1000 \mathrm{mg} \cdot \mathrm{dm}^{-3}$ の 塩素イオンを $\mathrm{NaCl}$ として添加したものを用いた。ま た, 一部の試験液については, 試験前に空気と窒素の混 合ガス（酸素濃度 : $10.2 \%$ ）で約 $30 \mathrm{~min}$ 間ばっ気し, 試験中，試験槽の空間部を同組成のガスで満たした。な お, 試験液の温度は $30^{\circ} \mathrm{C}$ とした。

\section{2 インピーダンス測定}

人工酸性雨は導電率が低いため, 通常の 3 電極法でイ ンピーダンスを測定すると高周波数帯域において誤った
結果が得られることがある19)。そこでここでは, 被測定 系のインピーダンスをできるだけ小さくするために, 試 験面を大きめ $\left(20 \mathrm{~cm}^{2}\right)$ にした 2 枚の試験片を $400 \mathrm{~cm}^{3}$ の試験液中で約 $3 \mathrm{~mm}$ 離して対向させ， 2 電極法によ りインピーダンスを測定した。ただし，回転円盤電極を 用いた実験では試験面を大きくすること，および 2 電極 法を適用することが困難であったため, 導電率が比較的 高い試験液 $\left(\mathrm{Cl}^{-}\right.$濃度 $\left.>100 \mathrm{mg} \cdot \mathrm{dm}^{-3}\right)$ に限り 3 電極 法によりインピーダンスを測定した。また，この場合に も測定誤差をできるだけ抑えるため, 照合電極として用 いた飽和甘こう電極のガラス容器内に Pt 線を挿入し, $0.1 \mu \mathrm{F}$ のコンデンサを介して照合電極に並列に接続し た。

インピーダンス測定は周波数応答解析装置 (Solartron 1260) とポテンシオスタット (Solartron 1286) をパーソナルコンピュータ（NEC PC-9801 DA）で制 御して行い, 振幅は $10 \mathrm{mV}$ (peak to peak), 周波数範 用は $0.01 \mathrm{~Hz} \sim 10 \mathrm{kHz}$ とした。

\section{3 皮膜に関する測定}

銅試験片上に生成した皮膜の構造を知るために，40 $\mathrm{cm}^{3}$ の試験液中に試験面 $4 \mathrm{~cm}^{2}$ の試験片を $30 \mathrm{~min}$ 間浸 せきした後, 窒素で脱気した $0.1 \mathrm{~mol} \cdot \mathrm{dm}^{-3} \mathrm{KCl}$ 水溶 液 ${ }^{20)}$ 中にただちに移して定電流カソード分極し, 電位の 経時変化を測定した。照合電極には飽和甘こう電極を用 い, 液温は $30^{\circ} \mathrm{C}$, 電流密度は $200 \mathrm{~mA} \cdot \mathrm{m}^{-2}$ とした。

一部の試験片については, 大気中で FT-IR（フーリ 工変換赤外分光法）により皮膜の構造を分析した。

\section{4 銅溶出量の測定}

銅試験片の溶出量を知るために, 試験面 $40 \mathrm{~cm}^{2}$ の試 験片を試験液 $400 \mathrm{~cm}^{3}$ 中に $1 \mathrm{~h}$ 間浸せきし, 液中に溶 出した銅を ICP 発光分析法により測定した。

\section{3. 結果および考察}

\section{3. $1 \mathrm{pH}$ の影響}

\subsection{1 インピーダンス}

Fig. 1 は, 人工酸性雨の $\mathrm{pH}$ を $2.1 \sim 4.3$ の範囲で変 え，自然空気溶存下で $30 \mathrm{~min}$ 間浸せきした銅のイン ピーダンス軌跡を示したものである。これによれば，イ ンピーダンス軌跡は時定数の異なる少なくとも 3 種類の 素過程があることを示し，それぞれに対応する周波数帯 域は，約 $0.01 \sim 0.1 \mathrm{~Hz}$ ，約 $0.1 \sim 10 \mathrm{~Hz}$ ，約 $10 \mathrm{~Hz} \sim 10$ $\mathrm{kHz}$ となっている。インピーダンス軌跡全体の大きさ は, $\mathrm{pH}$ を 2.1 から 2.9 に上げてもわずかに増大するだ けであるが， 3.5 以上では $\mathrm{pH}$ の上昇にともなって著し く増大する。また，最も低い周波数帯域（約 $0.01 \sim 0.1$ $\mathrm{Hz} ）$ におけるインピーダンス軌跡は 2.9 以下の $\mathrm{pH}$ で ほぼ直線となり, 拡散過程を表す Warburg インピーダ 


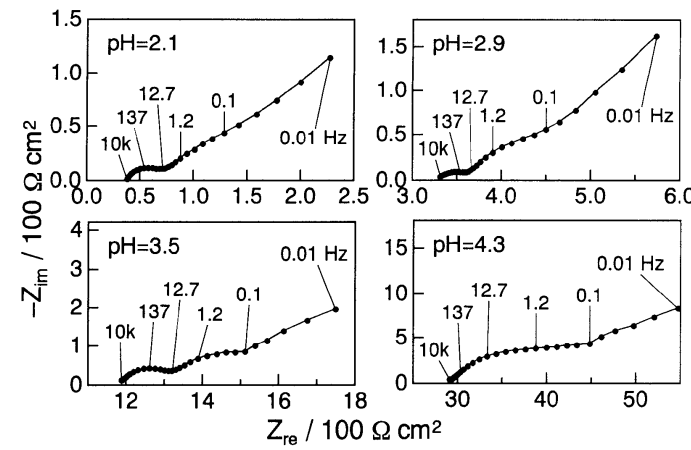

Fig.1 Effect of $\mathrm{pH}$ on the impedance diagram of $\mathrm{Cu}$ immersed in simulated acid rain : solutions were in equilibrium with the ambient atmosphere $\left(\mathrm{O}_{2}\right.$ concentration $\left.=20.8 \%\right)$; $30 \mathrm{~min}$ after immersion ; $30^{\circ} \mathrm{C}$.

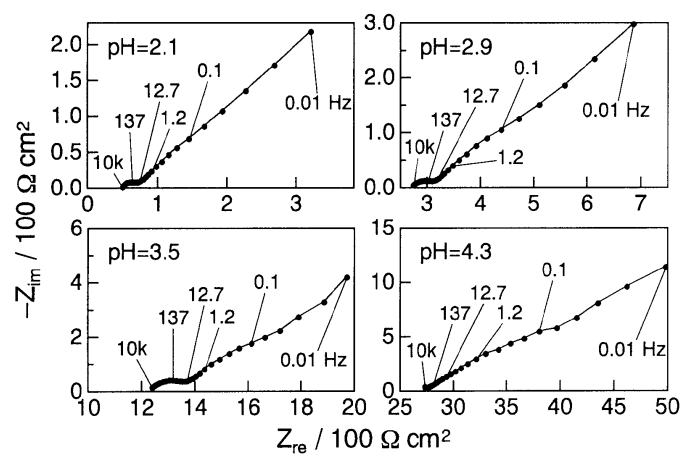

Fig.2 Effect of $\mathrm{pH}$ on the impedance diagram of $\mathrm{Cu}$ immersed in simulated acid rain : solutions were in equilibrium with the atmosphere which is the mixture of air and nitrogen $\left(\mathrm{O}_{2}\right.$ concentration $\left.=10.2 \%\right) ; 30 \mathrm{~min}$ after immersion; $30^{\circ} \mathrm{C}$.

\section{ンスにきわめて近い形状を示す。}

Fig. 2 は, 試験液中の溶存酸素濃度を約半分にし, その他の条件を Fig. 1 と同様にして测定したインピー ダンス軌跡を示したものである。Warburg インピーダ ンスと推定されるインピーダンス軌跡が全体に示す割合 は自然空気溶存下で測定したものよりも増大している。 また, $\mathrm{pH}=2.1$ では, $0.01 \sim 0.1 \mathrm{~Hz}$ の周波数帯域にお けるインピーダンス軌跡は傾きが約 45 度の直線となっ ており，ほぼ完全な Warburg インピーダンスの形状を 示している。このような結果から, $\mathrm{pH} 2.9$ 以下の試験 液中において，0.01〜0.1 Hzの周波数帯域で見られる インピーダンス軌跡は溶存酸素の拡散過程に対応するも のと考えられる。

\subsection{2 皮膜のカソード還元挙動}

Fig. 3 は, 種々の $\mathrm{pH}$ の試験液中に $30 \mathrm{~min}$ 間浸せき した試験片を, 窒素で脱気した $0.1 \mathrm{~mol} ・ \mathrm{dm}^{-3} \mathrm{KCl}$ 水

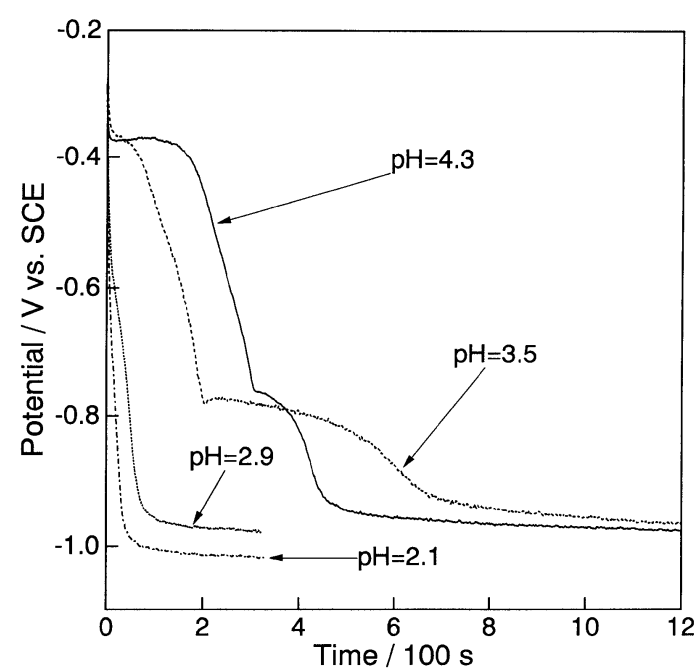

Fig.3 Potential-time curves for $\mathrm{Cu}$ in deaerated $0.1 \mathrm{~mol} \cdot \mathrm{dm}^{-3} \mathrm{KCl}$ under galvanostatic cathodic-polarization : $200 \mathrm{~mA} \cdot \mathrm{m}^{-2} ; 30^{\circ} \mathrm{C}$; $\mathrm{Cu}$ specimens were immersed in simulated acid rain for $30 \mathrm{~min}$ before polarization ; $\mathrm{pH}$ values indicated are for simulated acid rain.

溶液中において定電流カソード分極したときの電位-時 間曲線を示したものである。 $\mathrm{pH}=3.5$ および 4.3 の試 験液に浸せきした試験片では, $-0.4 \mathrm{~V}$ および $-0.8 \mathrm{~V}$ 付近に電位のプラトーが見られる。この実験とはべつ に, $200^{\circ} \mathrm{C}$ の大気中に銅試験片を $10 \mathrm{~min}$ 間放置し，表 面に生成した化合物を FT-IR で分析し，さらに同様に して定電流カソード分極したところ, 主成分は $\mathrm{Cu}_{2} \mathrm{O}$ であり, $-0.4 \mathrm{~V}$ 付近にその還元電位のプラトーが認め

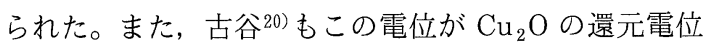
であると報告している。 $\mathrm{pH}=4.3$ では $-0.4 \mathrm{~V}$ 付近に おける還元時間が- $0.8 \mathrm{~V}$ 付近におけるそれよりも長 く, $\mathrm{Cu}_{2} \mathrm{O}$ を主成分とする皮膜が生成しているものと考 えられる。

これに対し, $\mathrm{pH}=3.5$ ではー $0.8 \mathrm{~V}$ 付近における還 元時間は $-0.4 \mathrm{~V}$ におけるそれよりも長く, $\mathrm{Cu}_{2} \mathrm{O}$ とは 異なる化合物が主成分となっているものと推定される。 一方, $\mathrm{pH}=3.5$ の試験液に $1 \mathrm{~h}$ 間浸せきした試験片を 大気中に取り出し, FT-IR で表面分析したところ, 主 成分は $\mathrm{Cu}_{2} \mathrm{O}$ であった。このような結果は, 液中での み安定な化合物が存在していることを示しているが，そ のような化合物を同定するためにはin situ レーザーラ マン分析などの in situ 測定が必要である。このことに ついては以後の検討課題としたい。

なお, $\mathrm{pH}=2.9$ 以下では酸化皮膜の還元を示す電位 のプラトーは認められず, 酸化皮膜がほとんど存在して いないことがわかる。 


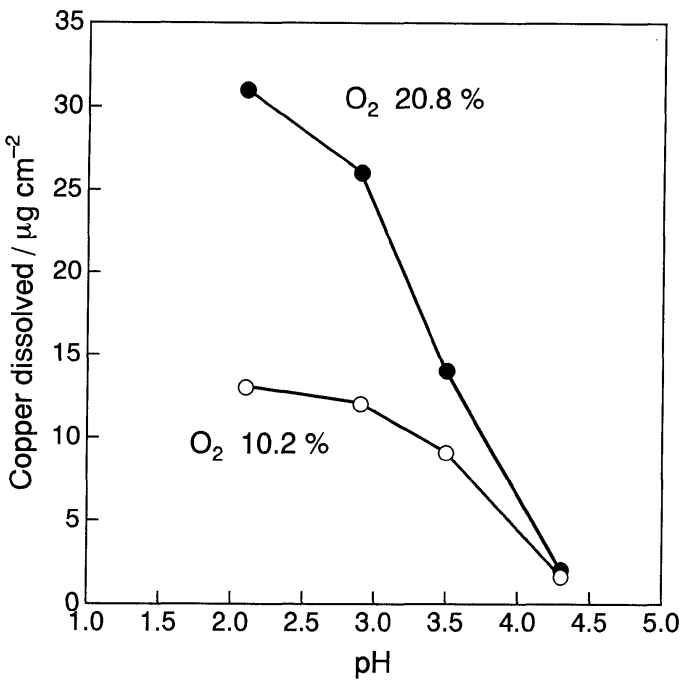

Fig.4 Effect of $\mathrm{pH}$ on the amount of $\mathrm{Cu}$ dissolved in simulated acid rain $: 30^{\circ} \mathrm{C} ; 1 \mathrm{~h}$.

\section{1 .3 銅の溶出量}

Fig. 4 は, 銅の溶出量を人工酸性雨の $\mathrm{pH}$ および酸 素濃度との関係で示したものである。これによれば，銅 の溶出量は $\mathrm{pH}$ の低下にともなって増大するが, $\mathrm{pH}$ が 低くなるにつれて溶出量に対する $\mathrm{pH}$ の影響は小さく なっている。このような傾向は雾囲気中の酸素濃度（以 下, 酸素濃度と略す) が低いほど著しく, 酸素濃度 10.2 $\%$ の場合, $\mathrm{pH}$ を 2.9 から 2.1 に低下させても溶出量 はほとんど変化しない。一方, 溶出量に対する溶存酸素 濃度の影響は $\mathrm{pH}$ が低いほど大きく, $\mathrm{pH} 2.9$ 以下では 溶出量は溶存酸素濃度にほぼ比例する。このような結果 から, $\mathrm{pH}$ の低下にともなって銅の溶解速度を支配する 過程が, 酸化皮膜の生成・溶解過程から溶存酸素の拡散 過程に移行していくものと考えられる。

\section{2 塩素イオンの影響}

\section{2.1 酸化皮膜の構造と厚み}

Fig. 5 は, 人工酸性雨 $(\mathrm{pH}=3.5)$, およびそれに塩 素イオンを 1 $1000 \mathrm{mg} \cdot \mathrm{dm}^{-3}$ 添加した水溶液中に $1 \mathrm{~h}$ 間浸せきした銅試験片表面の赤外スペクトルを示したも のである。なお, 元の人工酸性雨には $1 \mathrm{mg} \cdot \mathrm{dm}^{-3}$ の塩 素イオンがすでに含まれているため, 眓中のスペクトル には添加量に $1 \mathrm{mg} \cdot \mathrm{dm}^{-3}$ 加えたものを塩素イオン濃度 として示した。いずれのスペクトルにも $\mathrm{Cu}_{2} \mathrm{O}$ よる吸 収ピーク $\left(646 \mathrm{~cm}^{-1}\right)$ が最も明瞭に現れており, その 吸光度は人工酸性雨に塩素イオンを添加することにより 増大するが, 塩素イオンを $100 \mathrm{mg} \cdot \mathrm{dm}^{-3}$ 添加した場合 の方が $1000 \mathrm{mg} \cdot \mathrm{dm}^{-3}$ 添加した場合よりも大きくなっ ている。 $\mathrm{Cu}_{2} \mathrm{O}$ による吸光度は酸化皮膜の厚みに比例す ることがすでに報告されており ${ }^{21)}$, 人工酸性雨中の塩素

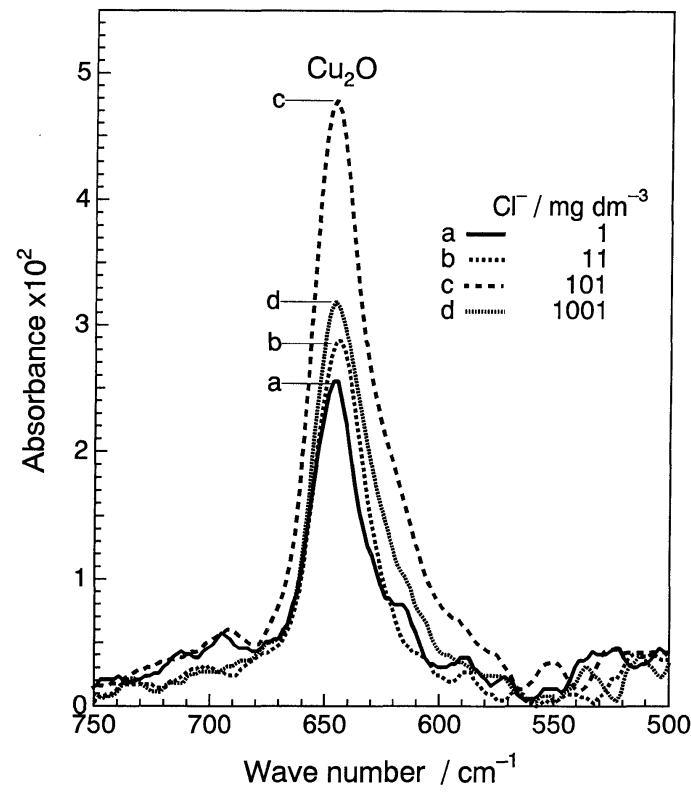

Fig.5 Infrared spectra of $\mathrm{Cu}$ specimens immersed in simulated acid rain for $1 \mathrm{~h}$ at $30^{\circ} \mathrm{C}$.

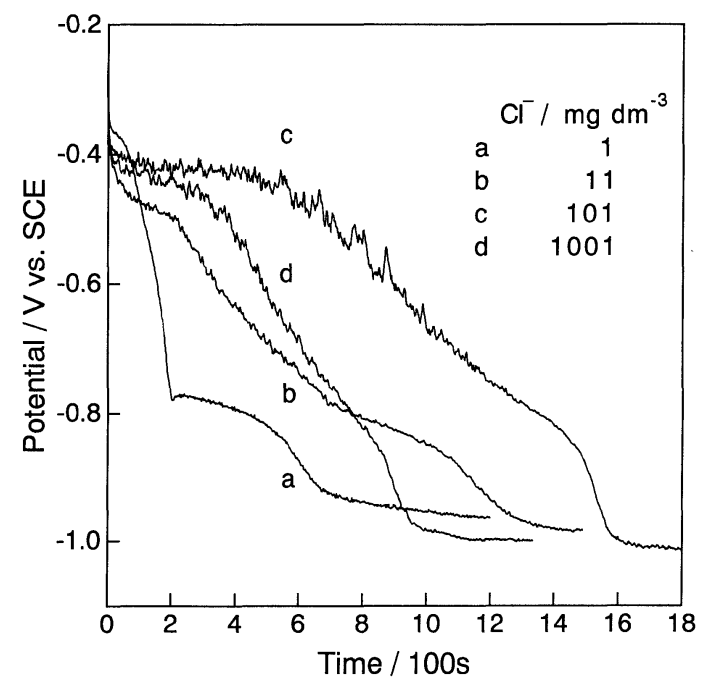

Fig.6 Potential-time curves for $\mathrm{Cu}$ in deaerated $0.1 \mathrm{~mol} \mathrm{dm} \mathrm{dm}^{-3} \mathrm{KCl}$ under galvanostatic cathodic-polarization : $200 \mathrm{~mA} \cdot \mathrm{m}^{-2} ; 30^{\circ} \mathrm{C}$; $\mathrm{Cu}$ specimens were immersed in simulated acid rain for $30 \mathrm{~min}$ before polarization ; $\mathrm{Cl}^{-}$concentration values indicated are for simulated acid rain.

イオン濃度を酸化皮膜の厚い順に並べると $101 ， 1001$, $11,1 \mathrm{mg} \cdot \mathrm{dm}^{-3}$ となる。

Fig. 6 に, 1〜 $1001 \mathrm{mg} \cdot \mathrm{dm}^{-3}$ の塩素イオンを含む人 工酸性雨 $(\mathrm{pH}=3.5)$ 中で生成した酸化皮膜の定電流力 ソード還元挙動を示す。すでに述べたように $-0.4 \mathrm{~V}$ 


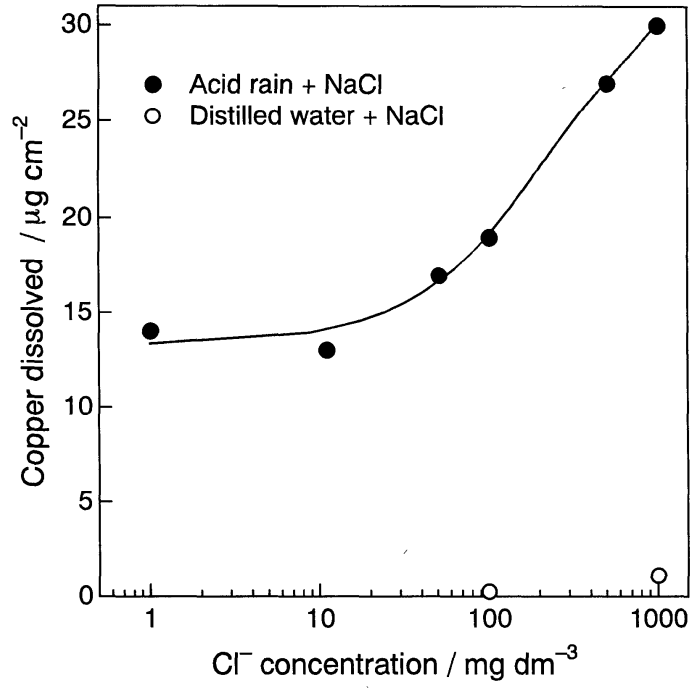

Fig.7 Effect of $\mathrm{Cl}^{-}$concentration on the amount of $\mathrm{Cu}$ dissolved in simulated acid rain : $30^{\circ} \mathrm{C} ; 1 \mathrm{~h}$.

付近のプラトーは $\mathrm{Cu}_{2} \mathrm{O}$ の還元に対応するが，このプ ラトーの長い順に塩素イオン濃度を並べると，101， 1001, $11,1 \mathrm{mg} \cdot \mathrm{dm}^{-3}$ となっている。このプラトーの 長さは皮膜中に含まれる $\mathrm{Cu}_{2} \mathrm{O}$ の量と相関を持つと考 えられ, $\mathrm{Cu}_{2} \mathrm{O}$ の量と人工酸性雨中の塩素イオン濃度の 関係は前記の赤外分光分析の結果と定性的に一致する。 なお，－0.4〜 -0.8V にかけての電位の緩やかな变化 は, 皮膜が $\mathrm{Cu}_{2} \mathrm{O}$ だけでなく他の化合物を含んでいる ことを示している。しかし，Fig. 5 の赤外分光分析結 果には $\mathrm{Cu}_{2} \mathrm{O}$ 以外に明瞭なピークが認められないことか ら, 溶液中でのみ安定な化合物が存在しているものと考 えられる。

\subsection{2 腐食速度と反応機構}

Fig. 7 は, 種々の濃度の塩素イオンを含む人工酸性 雨（ $\mathrm{pH}=3.5 ）$ 中に銅試験片を $1 \mathrm{~h}$ 間浸せきしたときの 銅溶出量を塩素イオンとの関係で示したものである。な お，図には蒸留水に $\mathrm{NaCl}$ を溶解した試験液中におけ る銅溶出量も合わせて示した。Fig. 7 によれば，人工 酸性雨中における塩素イオン濃度が約 $10 \mathrm{mg} \cdot \mathrm{dm}^{-3}$ 以 下の場合, 溶出量に対する塩素イオン濃度の影響はほと んど見られないが, 塩素イオン濃度がそれ以上になると 濃度の増大にともなって溶出量が増大することがわか る。一方, 蒸留水に $\mathrm{NaCl}$ を溶解した試験液中に浸せ きした試験片の溶出量は同じ濃度の塩素イオンを含む人 工酸性雨中に浸せきしたそれと比較して著しく小さく なっている。海塩粒子の付着した銅製構造物が霧のよう な少量の水分で濡れた場合, 付着液中の塩素イオン濃度 はかなり高くなると考えられる。このような場合, 霧が 酸性霧であるかないかの違いによって銅の腐食速度が大

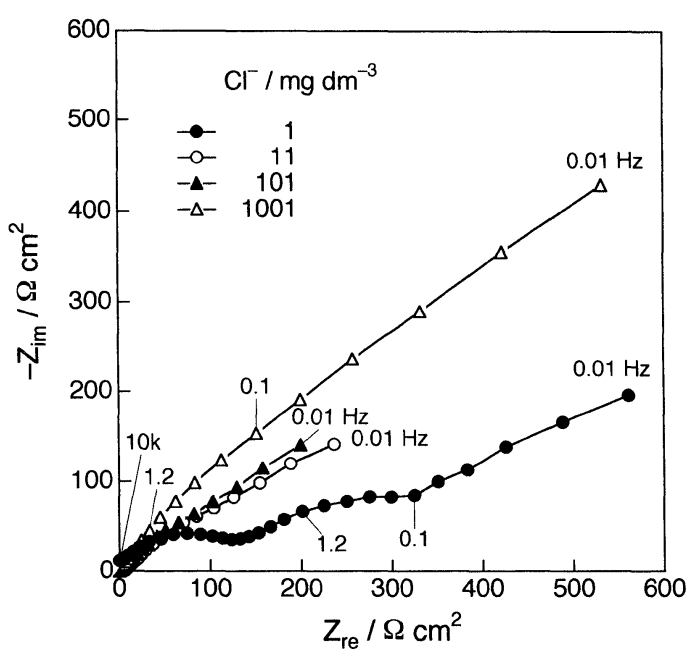

Fig.8 Effect of $\mathrm{Cl}^{-}$concentration on the impedance diagram of $\mathrm{Cu}$ immersed in simulated acid rain : $\mathrm{pH}=3.5 ; 30^{\circ} \mathrm{C} ; 30 \mathrm{~min}$ after immersion.

きく左右されることを Fig. 7 の結果は示している。

Fig. 8 は, 塩素イオン濃度の異なる人工酸性雨 （pH=3.5）中に銅試験片を $30 \mathrm{~min}$ 間浸せきしたとき のインピーダンス軌跡を示したものである。なお，比較 を容易にするために, 各インピーダンス軌跡の実数成分 には $10 \mathrm{kHz}$ における值（ほぼ液抵抗に相当）を減じた ものを示した。インピーダンス軌跡の形状は塩素イオン の添加によって変化し, 塩素イオン濃度が高いほど低周 波数帯域におけるインピーダンス軌跡は直線に近づく。 また, インピーダンス軌跡全体の大きさは, 塩素イオン の添加量が $100 \mathrm{mg} \cdot \mathrm{dm}^{-3}$ までは塩素イオン濃度の増大 にともなって減少するが, $1000 \mathrm{mg} \cdot \mathrm{dm}^{-3}$ 添加したも のでは逆に増大している。

一般に腐食の律速過程が変わらなければ，インピーダ ンス軌跡全体の大きさは腐食速度が増大するにしたがっ て小さくなるはずである。これに対し，塩素イオン濃度 $101 \mathrm{mg} \cdot \mathrm{dm}^{-3}$ と $1001 \mathrm{mg} \cdot \mathrm{dm}^{-3}$ の場合を比較すると, 後者の方が腐食速度が大きいにもかかわらずインピーダ ンス軌跡は逆に著しく大きくなっている。このような事 実は，塩素イオン濃度の増大にともなって腐食反応機構 に変化が生じていることを示している。

前記の赤外分光分析ならびに皮膜のカソード還元の結 果によれば，アノード反応としてはまず第一に，

$$
2 \mathrm{Cu}+\mathrm{H}_{2} \mathrm{O} \longrightarrow \mathrm{Cu}_{2} \mathrm{O}+2 \mathrm{H}^{+}+2 \mathrm{e}^{-}
$$

が考えられる。さらに，この反応で生成した $\mathrm{Cu}_{2} \mathrm{O}$ は,

$$
\mathrm{Cu}_{2} \mathrm{O}+2 \mathrm{H}^{+} \rightleftarrows 2 \mathrm{Cu}^{+}+\mathrm{H}_{2} \mathrm{O}
$$

により試験液中に溶解するものと考えられる。

また, 塩素イオンが存在する場合には,

$$
\mathrm{Cu}+\mathrm{Cl}^{-} \longrightarrow \mathrm{CuCl}+\mathrm{e}^{-}
$$




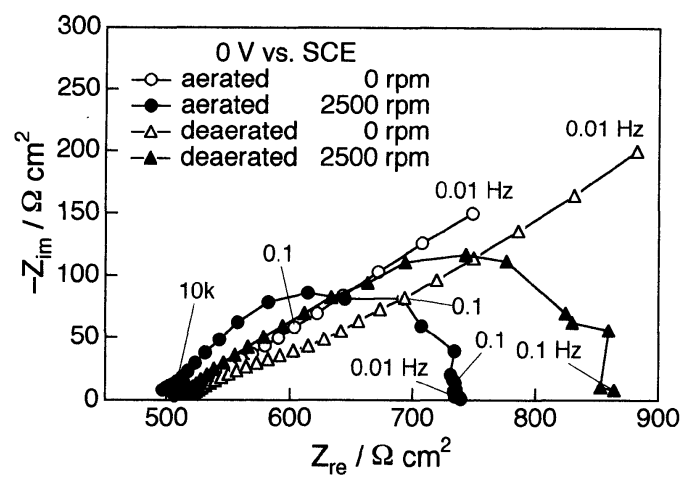

Fig.9 Impedance diagrams for a rotating disk of $\mathrm{Cu}$ in simulated acid rain containing 101 $\mathrm{mg} \cdot \mathrm{dm}^{-3} \mathrm{Cl}^{-}$.

なる反応も考えられ, 塩素イオン濃度の増大にともなっ て反応 (3)の占める割合が増大するものと思われる。反 応(3)が主反応の場合, さらに後続反応として,

$\mathrm{CuCl}+\mathrm{Cl}^{-} \longrightarrow \mathrm{CuCl}_{2}{ }^{-}$

が起こり, 銅の溶解反応は $\mathrm{CuCl}_{2}$-イオンの拡散律速に なると言われている15) 17)。

Fig. 9 は, 塩素イオン濃度 $101 \mathrm{mg} \cdot \mathrm{dm}^{-3}$ の人工酸 性雨中において, 自然空気溶存下における静止状態の腐 食電位に回転円盤電極の電位を設定し, 自然空気溶存下 $(\bigcirc, 0)$ および窒素で脱気した状態 $(\triangle, \boldsymbol{\Delta})$ で求めた インピーダンス軌跡を示したものである。回転速度 0 $\operatorname{rpm}$ のインピーダンス $(O, \triangle)$ には拡散に対応する部 分が見られるが, 全体の大きさは $2500 \mathrm{rpm}$ のもの

ム）とほとんど変わらず, 腐食速度に対する拡散過程の 寄与は小さいものと考えられる。

これに対し, 塩素イオン濃度 $1001 \mathrm{mg} \cdot \mathrm{dm}^{-3}$ のとき のインピーダンス軌跡（Fig.10）には拡散過程が明瞭 に現れている。すなわち, インピーダンス軌跡の大きさ を回転速度 $0 \mathrm{rpm}(\bigcirc, \triangle)$ と $2500 \mathrm{rpm}(\boldsymbol{O}, \boldsymbol{\Delta})$ で比 較すると, 後者の方が著しく小さく, 静止系における腐 食速度が拡散に支配されていることがわかる。また, 拡 散過程に対応するインピーダンス軌跡（約 $45^{\circ}$ の直線） は, 自然空気溶存下で求めたもの（○）にも脱気した溶 液中で求めたもの（ $\triangle ）$ にも共通に認められる。このよ うな事実から，腐食速度を支配する拡散物質は前述の $\mathrm{pH} 2.9$ 以下の人工酸性雨中で見られたような溶存酸素 ではなく，前記の反応(4)で生成する $\mathrm{CuCl}_{2}{ }^{-}$と考える のが最も自然である。

\section{4. 結言}

人工酸性雨中に浸せきした銅の腐食挙動について，定 電流カソード分極, 赤外分光分析, ICP 発光分析およ び電気化学インピーダンス解析を用いて検討した結果,

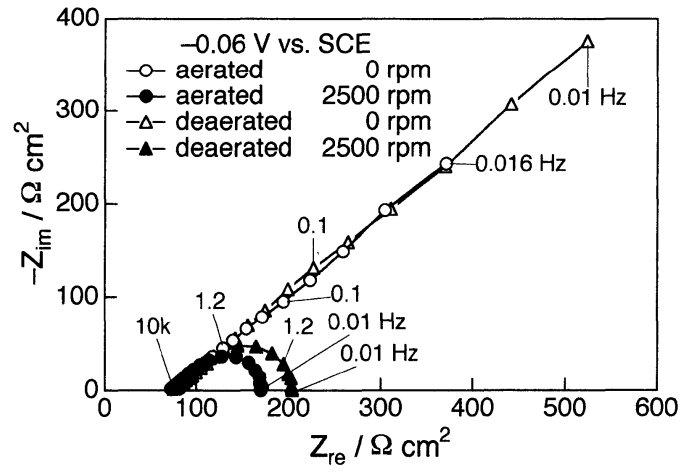

Fig.10 Impedance diagrams for a rotating disk of $\mathrm{Cu}$ in simulated acid rain containing 1001 $\mathrm{mg} \cdot \mathrm{dm}^{-3} \mathrm{Cl}^{-}$.

以下のことが明らかとなった。

1）人工酸性雨中における銅の腐食反応機構は, $\mathrm{pH}$ 約 3 を境にして大きく変化し, 腐食速度は, $\mathrm{pH}$ がそれ より高い場合には皮膜の生成・溶解反応過程に支配さ れ, それより低い場合には溶存酸素の拡散過程に支配さ れる。

2 ）人工酸性雨中における銅の腐食速度は塩素イオン 濃度の増大にともなって増大し, 同濃度の塩素イオンを 含む蒸留水中における腐食速度に比べて著しく大きい値 を示す。

3 ）酸化皮膜には酸化第一銅が含まれ，その厚みは塩 素イオンが一定量存在すると増大するが, 塩素イオン濃 度がある值を超えると逆に減少する。

4 ）上記の膜厚の減少は，溶解度の大きな塩化第一銅 の生成に対応し, 腐食速度は銅塩化物錯イオンの拡散過 程に支配されると考えられる。

なお，本研究で得られた結果はあくまでも人工酸性雨 中に短時間浸せきした銅の腐食挙動であって，実際の酸 性雨による銅の腐食反応過程は酸性雨の蒸発による濃縮 および乾燥過程を含むため，より複雑なものになると考 えられる。また本研究では $\mathrm{pH}$ の調整に硫酸を用いた が, 最近では硝酸系の酸性雨も多く見られるようになっ てきたため, 硝酸イオンの影響も検討課題として残って いる。以後, さらに検討を進める予定である。

(Manuscript received November 26, 1994 ; in final form December 21, 1994)

\section{文献}

1) 古明地哲人：材料と環境，41, 118 (1992).

2 ）古明地哲人 : 防錆管理, 38, 131 (1994).

3) K. Nassau, A. E. Miller \& T. E. Graedel : Corros. Sci., 27, 703 (1987).

4) J. P. Franey : Extended Abstracts for 68th Electrochem. Soc. Meeting, Las Vegas, 
USA, p.209 (1985).

5) E. Mattsson \& J. O’M. Bockris : Trans. Faraday Soc., 55, 1586 (1959)

$6)$ J. O'M. Bockris \& M. Enyo : Trans. Faraday Soc. , 58, 1187 (1962).

7) F. Chao \& M. Costa : Bull. Soc. Chim. Fr., 10, 4015 (1968).

8 ) T. Hurlen, G. Ottesen \& A. Staurset : Electrochim. Acta, 23, 39 (1978).

9 ) Q. J. M. Slaiman \& W. J. Lorenz : Electrochim. Acta, 19, 791 (1974).

10) Z. D. Stankovic : Electrochim. Acta, 28, 109 (1983).

11) A. de Agostini, E. Schmidt \& W. J. Lorenz : Electrochim. Acta, 34, 1243 (1989).

12) A. Jardy, A. L. Lasalle-Molin, M. Keddam \& H. Takenouti : Electrochim. Acta, 37, 2195 (1992).

13) G. G. O. Cordeiro, O. E. Barcia \& O. R.
Mattos : Electrochim. Acta, 38, 319 (1993).

14) D. K. Y. Wong, B. A. W. Coller \& D. R MacFarlane: Electrochim. Acta, 38, 2121 (1993).

15) H. P. Lee \& K. Nobe : J. Electrochem. Soc., 133, 2035 (1986).

16) D. Tromans \& R. Sun : J. Electrochem. Soc., 138, 3235 (1991).

17) F. K. Crundwell : Electrochim. Acta, 37, 2707 (1992).

18) S. A. Awad, Kh. M. Kamel, Z. Abd. El-Hadi \& H. A. Bayumi : J. Electroanal. Chem., 199, 341 (1986).

19) S. Chechirlian, P. Eichner, M. Keddam, H. Takenouti \& H. Mazille : Electrochim. Acta, 35, 1125 (1990).

20）古谷修一：防食技術，38，485（1989）.

21) G. W. Poling : J. Electrochem. Soc., 116, 958 (1969). 